\title{
The rise and manifestation of globalism and its implications for science
}

\author{
E.J. van Niekerk \\ Department of History of Education \\ University of South Africa \\ PRETORIA
}

\begin{abstract}
The rise and manifestation of globalism and its implications for science

The concept globalism refers to the interdependent and interconnected character of the contemporary world. One of the characteristics of the globalistic world order is that it is a threat unto itself. This threat is manifested in numerous global crises such as the population explosion, the extensive developmental disparities between First and Third World countries, the energy crisis, atomic warfare and the environmental crisis. Humanity has brought these and other global crises upon itself by the advancement of the modern (Western) industrial civilisation which emanated from the absolutised application of the natural scientific mode of thought.

In order to defend the thesis that the phenomenon of globalisation has profound implications for scientific practice, it is necessary to present a historical overview of the rise of globalism and an interpretation of its current manifestation. From these aspects one can deduce the significant implications that this phenomenon has for scientific practice. General features of a more accountable mode of scientific thought are also presented. Finally, Temporality Agogics, a paradigm within the context of History of Education, is discussed as an example of such a more accountable mode of scientific practice.
\end{abstract}

\section{Introduction}

The concept globalism refers to the interdependent and interconnected character of the contemporary world in all spheres such as politics, the economy, science and technology. It appears, however, as if the globalistic world order is a threat unto itself. This threat is manifested in numerous global crises such as the population explosion, the extensive developmental disparities between First and Third World countries, the energy crisis, atomic warfare and the environmental crisis. 
These are the most publicised problems our global world is experiencing. My contention is that these and other problems, such as those of a social, psychological and agogic nature, are directly related to the rise of globalism. These crises are the unbargained for side-effects of the modern Western industrial and postindustrial civilisation, and they arose from the absolutisation of the natural scientific mode of thought. Now, in the late twentieth century these global crises, some scientists reason, have brought humanity to a turning point (Findley \& Rothney, 1990:25; Capra, 1989; Peccei, 1981). The mode of scientific thought which led to the establishment of our high-tech, globalistic world, will have to undergo a radical re-orientation if we want to ensure a safe and meaningful future.

A re-orientation in scientific practice is, however, a complex and difficult issue because in scientific practice confusion appears to reign. This phenomenon exists because of the many divergent paradigms and the fragmentation of science into a multitude of disciplines among which there is little agreement concerning an encompassing meaningful structure for scientific thought and practice. It is ironic that now that humanity is faced with impending global catastrophies, there is little consensus on a mode of scientific practice that can secure a safe future for humanity. In this regard the humanities have a significant role to play.

The thesis of this article is that the phenomenon of globalisation has profound implications for scientific practice. It cannot and should not be ignored by the scientific community. In order to defend this thesis a historical overview of the rise of globalism and a description of its current manifestation will be given. From these aspects the implications that this phenomenon has for scientific practice will be deduced. General features of a more accountable mode of scientific thought than the scientific model which underlies globalism, will be presented. Finally, Temporality Agogics, a paradigm within the context of History of Education, will briefly be discussed as an example of such a more accountable mode of scientific thought and practice. Since the theme of this article is so comprehensive, only a broad overview will be presented, while at the same time an attempt will be made to focus on the essence of the matter.

\section{The rise of globalism}

Where does the interdependent and interconnected nature of our contemporary world come from? The rise of globalism can be traced back to the scientific revolution of the sixteenth and seventeenth centuries. This revolution led to a division between science and religion and, by emphasising the former, laid the foundation for vast development in the sphere of the natural sciences and technology (cf. Findley \& Rothney, 1990:9). Renaissance scientists like Copernicus (14731543), F. Bacon (1561-1626), G. Galilei (1564-1642) and R. Descartes (15961650) were the pioneers. Since the Renaissance, Western man has increasingly 
employed science and technology to discover, change and control his world. This new method of orientation in the world and towards the world led to the natural scientific discoveries that have enabled humanity to control the natural environment and to build up an industrial and technological civilisation. After the Industrial Revolution in the eighteenth century intensive technological application of scientific knowledge took place and what had been a predominantly agricultural civilisation became an industrial civilisation. Industrial civilisation is therefore firmly rooted in a natural scientific world view (cf. De Vleeschauwer, s.a.:1-47; Capra, 1989:22-23, 31-49; Ortega Y Gasset, 1962:9-10, 62-63, 158).

Prior to the rise of the natural sciences, human beings existed close to nature and did not attempt to control nature. The interdependence of man and the natural worlds was ingrained in people. This changed, however, with the establishment of an industrial and technological civilisation. Humanity now had power over nature. While seeking to dominate nature, humanity also brought about its own socio-political emancipation. The conquest of nature took place first (during the sixteenth and seventeenth centuries) and only thereafter (during the eighteenth century) did the emancipation of society from the old social and political order took place (cf. De Vleeschauwer, s.a.:1).

The rise and establishment of modern industrial civilisation was an important phase in the rise of globalism. The rise of the industrial economy goes hand in hand with political and economical imperialism. The industrial economy required more natural resources and this was one of the reasons for the imperialism of the European powers during the eighteenth and nineteenth centuries. The rise of globalism is related to industrialism since it was industrialism that required a globally integrated market. Because of this the world economy is now an interdependent unity. All facets of the economies of all countries, such as their industries, service sectors, standards of living, job creation and income levels are linked to the economies of their trading partners. Increasing globalisation is brought about by the central function that the marketplace has in a technological civilisation. The world market is increasingly interdependent and interconnected. (cf. Carbaugh, 1985:1, 195-196; Toffler, 1981:35, 73-74, 93-99, 101-109, 128, 297, 328-332; Van Niekerk, 1992:158-169). In the twentieth century products of the industrial civilisation like the motor car, the aeroplane and the telecommunication systems have given substance to the concept of a global village (Henn, 1991:43-71; Pelton, 1981:XII, 5-6; Toffler, 1981:47-49; De Beer, 1989:42). Through the application of modern science and technology, humanity has created the means for overcoming the restrictions that time and space had placed on them in the past. Figuratively speaking, the world has become a small place.

Industrial civilisation also had an impact on education. The development and maintenance thereof required that everybody should have at least basic education. 
The rise and manifestation of glohalism and its implications for science

A system of mass education, which began in the eighteenth century, is essential for both the maintenance of and for meaningful participation in the sophisticated and complex societal structure that has evolved (cf. Unesco, 1985:13-14, 27-31; Ulich, 1972:39; Toffler, 1981:44). Mass education is therefore inherently part of the form of civilisation that led to contemporary globalism. Mass education supplies the trained manpower that is essential for the continued development and advancement of industry and technology. At the same time it can also be used to promote globalism as an ideology.

The rise of globalism is also related to the rise of a uniform, popular mass culture (cf. Henn, 1991:176-195). Prior to the Industrial and the French Revolutions, society had been divided into two separate and distinct classes, the nobility and the peasants. The Industrial Revolution brought about a new class of people, the middle class. This numerous class had the same social, economic and cultural features and these features together with the leisure time that the mechanization of labour brought about, created a good market for entertainment. Thus it was the evolvement of the urbanized, democratic middle class that enabled the evolvement of a mass culture which is propagated by forms of entertainment and the mass media. Through the media of the twentieth century, i.e. films, radio and television, it is possible to reach large audiences and to influence them.

The globalistic nature of the mass culture that is propagated by the media is seen in the equalizing impact that it has on people and cultures. It breaks down differences of class, taste and culture, as well as the traditional commitment to language, ethnicity and religion. Traditional and different cultural groupings are drawn into a collective communality through the uniform mass culture. Mass production and the mass media created uniform needs and people with a uniform frame of reference and uniform expectations. Through technology mass culture is produced and marketed as a commodity product. The contemporary film and music industries are both the creators and the products of mass and popular culture on a global scale. Products of a high technical quality are produced, yet they also reveal an alarming superficiality. The shallowness of popular culture can be attributed to the fact that to be profitable, popular culture must serve as many people as possible and therefore its presentation is necessarily on a superficial level.

In the sphere of religion and morality the rise of globalism accompanied secularization. After the Renaissance secular humanism gradually became the dominant life and world view in the Western world. The growth of secular humanism can be directly attributed to the natural scientific mode of thought. In this mode of thought science acquires an autonomous character. Truth is sought via the scientific method and only via this method. Science replaces religion as the measure of truth, not only on the secular level, but also on the moral-ethical level. But science cannot answer humanity's most important question, namely: what is the 
E.J. van Niekerk

meaning and purpose of human existence in conjunction with the meaning and purpose of total reality. The human quest for ultimate meaning and truth is not taken into account in this mode of thought. It is therefore not surprising that this mode of thought led to secularism and a nihilistic refutal of God and the supernatural. Secular humanism created human beings whose actions are accountable only to human reason and not to God. Modern man orientates himself in the world through the application of reason, not through his belief in divine providence. Through the natural scientific and technological domination of the world, human beings have come to regard themselves as the masters of the world. There is no room for a Deity in such a world. Surrounded by a world of human technological achievement, man leads a godless life. Anthropocentrism is governed by the belief that there is no superior power to man. Nietzsche's maxim that God is 'dead' is therefore the most fundamental characteristic of the modern world (cf. Vycinas, 1973:3, 9; Ortega Y Gasset, 1962:158).

In the field of morality, humanity defines and deternines its own code of conduct. Norns, values and moral behaviour are no longer grounded in religious belief. This phenomenon has led to the relativism and the subjectivism in the field of morality that is rampant in our secular, globalistic world. Secularism gives rise to relativism and relativism is reinforced by globalism in that the globalistic nature of the world exposes people to different and conflicting views of ethically 'correct' behaviour. The impression is created that none of these views has absolute validity and consequently, any and all behaviour becomes acceptable in a global world. Because of secularization there is no longer a central, focal point for moral orientation. Findley and Rothney (1990:25) warn that the processes of secularization cannot go much further without aggravating the already serious sense of moral drift.

\section{The contemporary manifestation of globalism}

Globalisation is manifested in all walks of life: in science and teclinology, the economy, politics, religion, morality and education. The phenomenon of globalisation is a complex and burning issue and it has changed the life-world of twentieth-century people. I have already discussed globalism's relation to the modern industrial civilisation, to a system of public education, to a uniform, popular mass culture and to secular humanism. In this section the focus will be on the crisis in which our global technological civilisation finds itself. Globalism manifests itself in a particularly destructive way in the current global problems of atomic warfare, the extensive developmental disparities between First and Third World countries, the energy crisis, the environmental crisis and the population explosion. The interconnected and interdependent nature of our world is clearly illustrated through these problems which affect all people. In order to support the thesis that the phenomenon of globalisation has profound implications for scientific practice, 
The rise and manifestation of globalism and its implications for science

it will be indicated how each of these contemporary global problems are related to the application of a positivistic mode of thought.

\subsection{Population explosion}

Before the rise of medical science the human population was controlled by inter alia plagues, famine and war. Progress and improvement in medical services, sanitation and nutrition in the technological era brought down the death rate among children while simultaneously increasing life expectancy. After the Industrial Revolution population numbers increased in Europe, with a particularly sharp increase during the nineteenth century. In the late twentieth century, however, the number of births decreased in the West due to education and economic growth. In this century public health care has improved worldwide. This factor, in conjunction with other factors, has subsequently led to an increase in the world population from 1.7 billion in 1900 to 5 billion in 1986 and it is expected to double again by 2050 .

These numbers threaten both the man-made environment as well as the natural environment. It is feared that the population pressure on the environment may result in a global catastrophe. The population explosion also aggravates other global problems. The population problem, created by human beings, therefore affects humanity's future and it can be ascribed to the positivistic control of nature (cf. Findley \& Rothney, 1990:11, 512-514; Peccei, 1981:31, 33; Van Niekerk, 1992:156-157).

\subsection{Developmental disparities}

The developmental problem can also be called the equity or the poverty problem. It is the problem of developmental inequality between countries where development is measured in terms of technological advancement. The world is currently divided into a so-called developed, rich part (i.e. North America, Western Europe and Japan) and the underdeveloped, poor part which includes approximately one billion people living on the verge of starvation. The developmental problem is magnified by the rapid increase in population in the poorer parts of the world. The division of the world into the affluent North and the hungry South affects everybody in the globalistic, interdependent world of today. It is, however, doubtful whether it will be possible to divide the advantages of technology on a more equitable basis in future. It should be born in mind, however, that though an increase in industrialization may promote equity, it does also increase the disadvantages associated with a technological civilisation such as the global problems already mentioned (Findley \& Rothney, 1990:4; Gribbin, 1981:10, 55, 58; Mohr, 1973:165-166; Peccei, 1981:74-80; Van Niekerk, 1992:150-153, 220-225). 


\subsection{Energy crisis}

Newcomen's design of a workable steam engine in 1712 was the start of the consumption of fossil fuels such as coal and oil. These, however, cannot serve as a permanent energy source. Fossil fuels can be depleted and they also create great pollution problems. Indeed, the whole energy base of our civilisation is now a subject of intense debate. Greater energy efficiency in the short run and the development of renewable, non-polluting energy sources in the long run seem to be the only viable options to the energy crisis. Till these solutions are found, fossil fuels continue to pollute us and our environment (Toffler, 1981:39, 144145; Findley \& Rothney, 1990:517-519; Van Niekerk, 1992:153-154).

\subsection{Environmental crisis}

Unrestricted economic and technological growth and the excessive exploitation of the natural environment has disturbed the dynamic balance in the earth's ecosystems. Because of the supra-ideology of the industrial era, which entails that human beings dominate nature, the exploitation of nature has escalated to such an extent that the biosphere is sending out alarm signals. Pollution, protection of various species, excessive cultivation, deforestation, desertification, acid rain, global warming, climatic change and ozone depletion are some of the major environmental problems which the world has to face (Capra, 1989:24-25; Toffler, 1981: 112, 134, 245-246; Khalid, 1989:19-21; Bybee, 1991:147; Van Niekerk, 1992: $154-156,225-227$ ).

\subsection{World peace}

In the twentieth century scientific and technological progress has given humanity the ability to manufacture weapons (like the atomic bomb) which can destroy the world. Peccei (1981:82) talks about “... self-destruction by strictly scientific means". The human craving for power through the natural scientific mode of thought has brought us to the brink of global disaster. World peace is required for the continued existence of our globalistic world (Findley \& Rothney, 1990: 530-541; Van Niekerk, 1992:148-150, 217-220).

The intercomected nature of global problems in a globalistic era makes it particularly difficult to address these issues. Global problems have made the world interdependent and intercomected because all people are threatened by these problems and all have a part to play in seeking solutions. Not only the politicians have a part to play. Even children are exposed to these crises in the curricula for global education in some countries (cf. Heater, 1980:16-23; Tonkin \& Edwards, 1981:40; Hicks \& Townley, 1982:3-4, 10; Alger \& Harf, 1986:1; Pike \& Selby, 1988:63-69; Van Niekerk, 1992:148-150, 217-220). Our globalistic world, foun- 
The rise and manifestation of globalism and its implications for science

ded on the natural scientific mode of thought, is in a state of crisis. The scientific community must take the lead in addressing this crisis.

\section{The implications of globalism for science}

Human beings have created a threatened and an insecure world through the absolutisation of the natural scientific (calculative, positivistic or quantitative) mode of thought which was prevalent not only in the natural sciences, but also in the human sciences. However, the optimism associated with the modernistic belief that natural science will in time solve all problems and that it is possible to control reality in its totality is dwindling. The 'blessings' that natural science and modern technology have brought are being overshadowed by the natural scientific mode of thought's failure to generate a secure, dignified and meaningful future existence for humankind. This is a disturbing thought to a mind dominated by secular humanism, because it clearly illustrates human failure. It is also disturbing to scientists, because it reveals the failure of the scientific community to foresee the consequences of the application of a specific mode of scientific thought which has led to the global state of crisis. Even more disturbing to scientists, is the fact that though these crises can be analysed, no quick-fix solution has or can be presented.

This poses a serious challenge to all scientists. Human scientists must play their part in answering this challenge. That which has gone wrong in scientific practice needs to be rectified. There is a dire need for a more accountable scientific mode of thought. Scientists have a moral obligation in these insecure circumstances to reflect on scientific practice and how it should be changed so that human beings can, in future, lead more secure, more dignified and more meaningful lives.

In the introduction to this article it was stated that the many divergent paradigms and the fragmentation of science into a multitude of disciplines constitute part of the problem. There appears to be no encompassing philosophy of science which can meaningfully direct scientific practice. What is needed is a frame of reference which can direct the scientific community. Modernism appears to have failed, and postmodernism too does not seem to provide the necessary answers and solutions.

A meaningful common frame of reference can be achieved in three possible ways:

* Firstly, by providing and establishing meta-paradigmatic or meta-epistemological criteria for the evaluation of scientific practice. These criteria will hopefully direct scientific practice away from disastrous directions (such as the crises that the positivistic orientation created). 
* Secondly, by maintaining the correct balance between a natural scientific or quantitative and a qualitative or meaning-searching mode of thought. This means that the meaning-searching mode of thought should give meaningful direction to quantitative thinking, which implies that the scientist will consciously and consistently ask what the meaning and purpose of scientific practice is.

* Thirdly, by closing the gap between science and religion that was brought about by the natural scientific orientation after the Renaissance. (See Van Niekerk, 1992:318-319.)

The third option appears to be the best option since it actually includes the other two options. Religion gives meaningful answers to the human search for meaning and also provides criteria for a meaningful human existence and all human activities, including scientific research. The only meaningful answer to the question of the meaning and purpose of human existence in conjunction with total reality is given in religion. This is why scientists should rise above the secular mode of scientific practice which absolutised science and led to the crisis in which our globalistic world finds itself

Globalism poses an epistemological challenge to human scientists. We should respond to this challenge with a more accountable scientific mode of thought. Bearing in mind the three possibilities that have been identified as a possible frame of reference for meaningful scientific practice, the following is a general outline of a more accountable scientific mode of thought:

* An accountable scientific model should not work in a purely quantitative (positivistic/calculative or natural scientific) mamer, but should be open to a meaning-searching (qualitative or reflective) mode of thought. An accountable scientific model should harmonise scientific enterprise with the human search for meaning. This means that, in order to be a meaningful enterprise, scientific enterprise should relate to the purpose and meaning of human existence. In this way the correct balance between the quantitative and the meaning-searching mode of thought can be found, because the meaning and purpose of human existence in conjunction with the meaning and purpose of total reality is sought

* Science, which is practised by human beings and which has a major effect on humanity in its practical application, should take the true nature of human beings into account. Human beings should be viewed in the wholeness of their relatedness. A secular scientific model, such as the natural scientific model, does not view human beings in the wholeness of their relatedness to other human beings, total reality and Ultimate Reality (or God), and therefore cannot assist or direct the human search for meaning. A secure future for humanity can only be built on a scientific model that takes cognisance of 
The rise and manifestation of globalism and its implications for science

the fact that human beings do not only relate to things and to other human beings, but also to Ultimate Reality/God

* Scientific practice is characterised by openness, since scientific research is a human search for truth and validity. However, Truth and Meaning in its purest form, that is God, can never be made an object of scientific research or be explained in a scientific way. However open scientific research may claim to be, an accountable scientific mode of thought will also have to acknowledge that science has limitations

* An accountable scientific mode of thought should acknowledge that scientific practice is a normative undertaking. A totally objective, value-free, neutral or presuppositionless type of science is impossible. For this reason academic freedom should not be absolutised and accountability on the part of scientists must not be underemphasised. The values and nonns underlying a scientific model and the scientist's convictions in this regard should be debated and evaluated from a meaning-searching perspective.

* The rift that was brought about between science and religion through the overemphasis of a quantitative (calculative or natural scientific) mode of thought has had tragic consequences. We should discard purely humanistic scientific practice. This mode of thought has jeopardized our future because it did not incorporate a meaning-searching mode of thought. (Smith, 1991, 1993; Breitenbach, 1991; Van Niekerk, 1992.)

On the basis of such a paradigm shift it should be possible to engender a more secure, more dignified and more meaningful future for humankind in the long run. Even if we are pessimistic about the possibility of a meaningful re-orientation of our technological civilisation, we still have the duty to prepare the way for such a re-orientation.

\section{Temporality Agogics as an example of accountable scientific practice}

Are there examples of such a paradign? Yes, amongst others Temporality Agogics which is a paradigm employed by some scientists in the History of Education. The general outlines of an accountable scientific mode of thought that was presented in the previous section were in fact derived from the epistemological challenge of globalism and also from Temporality Agogics as a paradigm. It is impossible to describe this paradigm fully within the scope of this article (cf. Pienaar, 1974, 1975, 1976, 1979, 1980, 1988, 1990; Breitenbach, 1991; Smith, 1977, 1983, 1987, 1991, 1993; Van Niekerk, 1992) and therefore only some broad outlines (which are relevant to this discussion) will be presented. Those interested can read the above sources for more information on this paradigm. 
The phenomenon of human accompaniment is described in the science of Agogics. The name Temporality Agogics indicates that in this paradigm the phenomenon of human accompaniment is studied from a time perspective. However, in Temporality Agogics the focus is not on knowledge about the past that can be obtained in a purely quantitative manner. The focus in Temporality Agogics is to use the knowledge about the phenomenon of human accompaniment which is obtained from the past in order to give directives for meaningful present and future human accompaniment.

In Temporality Agogics the meaning and purpose of human accompaniment is interpreted against the background of the meaning and purpose of human existence in conjunction with the meaning and purpose of total reality. The meaningsearching mode of thought is incorporated into this paradigm because it acknowledges the intricate relationship between human accompaniment and the human search for meaning. In Temporality Agogics the meaning-searching mode of thought is grounded in temporality. Temporality and the temporal character of human existence make it possible to think in a meaning-searching way. One cannot think meaningfully about the true nature of meaning and truth if the temporal nature of human existence is not taken into account. This can be illustrated by referring to the phenomenon of human accompaniment.

The concept of time is intricately involved in the phenomenon of human accompaniment. A human being is born at a specific time and dies at a specific time, and between birth and death human beings should learn, through human accompaniment, how to live meaningful lives. The aim of accompaniment is directed towards a meaningful human existence. This goal can only be accomplished if an ultimate destination in time - a destination which can be claimed to be a meaningful destination - is kept in mind. The ultimate destination of a meaningful human existence has to be related to man's eternal destination, which is defined by his religion. The eternal destination of human beings is accounted for in religion.

All human accompaniment takes place in time. This is precisely why the temporal nature of human existence should be taken into account in human accompaniment. It is impossible to understand the true nature of being human if the temporal dimension of our existence is not fully comprehended. Taking this dimension into account does not only imply that the past, present and future of our earthly existence is dealt with. It also implies that one should take into account that human beings feel called upon to fulfil an eternal calling related to a religiously defined eternal destination, which gives meaning to their earthly lives. The human perception of time includes a consciousness of the relation between time and timelessness or eternity. This consciousness is clearly manifested in the human longing for security within the context of a particular religion. The human quest for meaning is clearly related to religious belief. 
The temporal dimension of our existence has to be taken into account in order to be able to accompany human beings towards a meaningful existence. The temporal dimension is taken into account in Temporality Agogics, as is the meaningsearching mode of thought, which is grounded in temporality. The meaningsearching mode of thought should be an essential component of authentic scientific practice. Temporality Agogics also acknowledges that this mode of thought relates to the temporal nature of human existence. An accountable scientific model should take into account that the temporal character of human existence has important implications for scientific practice. Academics should consider these implications.

\section{Conclusion}

The context of human thinking and scientific practice should be broadened and a fragmented approach and vision of reality avoided. Scientists can do this by recognising and accommodating the meaning-searching mode of thought. In this regard Christian scientific practice could serve as an example, since Christian science is practised within the meaningful context of the Christian life and world view.

\section{References}

ALGER C.F. \& HARF, J.E. 1986. Global Education: Why? For Whom? About What? (In Freeman, R.E., ed Promising Practices in Global Education: a Handbook with Case Studies. New York : National Council on Foreign Language and International Studies. p. 31-33.)

BREITENBACH, T.C. 1991. 'n Meta-paradigmaties kriteriale ondersoek na denkmodelle binne die konteks van die Temporaliteitspedagogiek. Port Elizabeth : Universiteit van Port Elizabeth. (D.Ed-proefskrif)

BYBEE, R.W. 1991. Planet Earth in Crisis: How Should Science Educators Respond? The American Biology Teacher, 53(3): 146-153.

CAPRA, F. 1989. The Turning Point. Science, Society, and the Rising Culture London Fontana Paperbacks.

CARBAUGH, R.J. 1985. International Economics. (2nd edition). Belmont, Calif: Wadsworth Publishing Company.

DE BEER, C.S. 1989. Between the Scylla and Charybdis of Technical Progress. RSA 2000 Gesprek met die toekoms, $11(2): 38-52$.

DE VLEESCHAUWER, H.J. s.a. Geskiedenis van die Wysbegeerte in die Weste. Band 3 Die Wysbegeerte van die moderne tyd (van die Renaissance tot Hegel). Kaapstad Nasou.

FINDLEY, C.V. \& ROTHNEY, J.A.M. 1990. Twentieth-Century World. (2nd edition.) Boston : Houghton Mifflin Company.

GRIBBIN, J. 1981. Future Worlds. New York : Plenum Press.

HEATER, D. 1980. World Studies: Education for International Understanding in Britain. London : Harrap 
HENN, P.J. 1991. 'n Temporaliteitspedagogiese deurskouing en evaluering van die globalisme en die strewe om die onderwys en opvoeding te globaliseer. Pretoria : Universiteit van Suid-Afrika. (M.Ed.-verhandeling.)

HICKS, D. \& TOWNLEY, C., eds. 1982. Teaching World Studies. An Introduction to Global Perspectives in the Curriculum. London : Longman.

KHALID, M. 1989. The Greatest Challenge, the Greatest Opportunity: Preparing Our Children for a Common Future. Imternational Schools Journal, 7: 18-26.

MOHR, F.R. 1973. Wat gaat er nu eigenlijk mis? Mentale achtergronden van onze veranderende wereld. Deventer : Uitgeverij Ankh-Hermes.

ORTEGA Y GASSET, J. 1962. Man and Crisis. (Translated by M. Adams.) New York : W.W. Norton \& Co.

PECCEI, A. 1981. One Hundred Pages for the Future. Reflections of the President of the Club of Rome. New York : Pergamon.

PELTON, J.N. 1981. Global Talk. The Marriage of the Computer, World Communications and Man. Brighton : The Harvester Press.

PIENAAR, J J. 1974. Temporaliteitspedagogiek. Port Elizabeth : Universiteit van Port Elizabeth. (Navorsingspublikasie C6, Universiteit van Port Elizabeth Publikasiereeks.)

PIENAAR, J.J. 1975. Die temporaliteitsbegronding van die pedagogiek. Port Elizabeth : Universiteit van Port Elizabeth. (Intreerede D9, Universiteit van Port Elizabeth Publikasiereeks.)

PIENAAR, J.J. 1976. Die periagogiese karakter van die opvoeding. Suid-Afrikaanse Tydskrif vir die Pedagogiek, 10(2): 51-69

PIENAAR, JJ. 1979. Temporaliteitspedagogiek - 'n sinsoekende bevraging. SuidAfrikaanse Tydskrif vir die Pedagogiek, 13(2): 13-27.

PIENAAR, J.J. 1980. Die Kehre-denke by o.a. Heidegger en die agogiese betekenis daarvan. Pretoria : Universiteit van Pretoria. (D.Phil.-proefskrif.)

PIENAAR, J.J. 1988. Die Temporaliteitspedagogiek - 'n waarheid- en sinsoekende begronding. Professorale intreerede aan die Universiteit van Suid-Afrika. Pretoria : Universiteit van Suid-Afrika.

PIENAAR, J.J. 1990. 'n Eksemplariese veldondersoek na en 'n fundamentele besinning oor die stand, die aard en wese van die Historiese Opvoedkunde asook die geldigheidswaarde en die sinvolheid daarvan vir die onderwysteorie en -praktyk. Navorsingsverslag, Historiese Opvoedkunde. Pretoria : Universiteit van Suid-Afrika

PIKE, G. \& SELBY, D. 1988. Global Teacher, Global Learner. London : Hodder \& Stoughton.

SMITH, T.G. 1977. 'n Metableties-eksemplariese deurskouing van die Paideiastruktuur. 'n Studie in die Temporaliteitspedagogiek. Port Elizabeth : Universiteit van Port Elizabeth. (M.Ed -verhandeling.)

SMITH, T.G. 1983. Die periagogiese denkverloop as 'n poging tot outentieke agogiese denke. Port Elizabeth : Universiteit van Port Elizabeth. (D.Ed.-proefskrif.)

SMITH, T.G. 1987. Outentieke, inoutentieke denke en opvoeding. Fducare, 16(1): 39-50.

SMITH, T.G. 1991. Die Historiese Opvoedkunde - 'n Temporaliteitspedagogiese denkverloop. (In Steyn, J.C., red. Onderwys in transformasie: opstelle in die Historiese Opvoedkunde. Stellenbosch: Universiteitsuitgewers en -boekhandelaars. p. 1-29.)

SMITH, T.G. 1993. Die implikasies van 'n metaparadigmatiese benadering vir die beoefening van die Historiese Opvoedkunde. Stellenbosch : Universiteit van Stellenbosch. (D.Phil.proefskrif.)

TOFFLER, A. 1981. The Third Wave. London : Pan Books.

TONKIN, H. \& EDWARDS, J. 1981. The World in the Curriculum. Curricular Strategies for the 21 st Century. New York: Change Magazine Press. 
The rise and manifestation of globalism and its implications for science

ULICH, R. 1972. Progress or Disaster. From the Bourgeois to the World Citizen. London University of London Press.

UNESCO. 1985. Reflections on the Future Development of Education. Paris : Unesco.

VAN NIEKERK, E.J. 1992. 'n Temporaliteitspedagogiese ontleding en evaluering van die globaliseringsverskynsel. Pretoria : Universiteit van Suid-Afrika. (D.Ed.-proefskrif.)

VYCINAS, V. 1973. Our Cultural Agony. The Hague : Martinus Nijhoff. 